Kara, Y. (2019). Zihinsel Yeti Yitimi Olan Çocuğa Yönelik Sosyal Hizmet Uygulaması: Bir Vaka Sunumu. Toplum ve Sosyal Hizmet, 30(1), 353-373.

Vaka Sunumu

Makale Geliş Tarihi:17.10.2018

Makale Kabul Tarihi: 19.12.2018

\title{
ZiHINSEL YETI YiTIMI OLAN ÇOCUĞA YÖNELIK SOSYAL HIZMET UYGULAMASI: BIR VAKA SUNUMU
}

\section{A Case Study: Social Work Practice in for Child who Have Intellectual Disabilities}

\section{Yunus KARA*}

* Arş. Gör., Altınbaş Üniversitesi, İktisadi, İdari ve Sosyal Bilimler Fakültesi, Sosyal Hizmet Bölümü, e-posta: yunus.kara@altinbas.edu.tr, ORCID ID: 0000-0002-7812-5845

\section{ÖZET}

Bu makalede zihinsel yeti yitimi olan çocuğa yönelik uygulanan sosyal hizmet müdahale süreçleri ele alınmıştır. Çalışma yapılan vaka T.K. on dört yaşında olup, ortaokul yedinci sınıfta kaynaştırma öğrencisidir. Eğitimine devam etmekteyken davranış problemleri göstermesi ve ögrretmenlerinin onu kendi sınıflarında istememesi üzerine okulun özel eğitim sınıfına yönlendirilmiş ve eğitimine burada devam etmesi sağlanmıştır. Özel eğitim sınıfındaki akademik başarısı ve davranış örüntüleri takip edilmiş, bu süreç içerisinde kendisiyle ve ailesiyle görüşülmüş; birey, aile ve toplum düzeyinde neler yapılabileceği üzerinde durulmuştur. Vaka, genelci sosyal hizmet yaklaşımı açısından ele alınarak, T.K.'nın içe ve dışa dönük davranış problemlerinin çözümlenmesi için okul sosyal hizmetinin uygulamaya geçirilmesi ve diğer alternatif sosyal hizmet modelleri açısından değerlendirilmiştir.

Anahtar kelimeler: Okul sosyal hizmeti, Sosyal hizmet uygulaması, Zihinsel yeti yitimi.

\section{ABSTRACT}

The social work intervention processes applied on a child with mental disability is discussed in this article. In the discussed case, T.K. is fourteen years old and is an inclusive student in 
the seventh grade of secondary education. Because he had behavioural in class and his teachers did not want him in their class, he was directed to the special education class of the school and he was ensured to continue his education there. The academic success and behavioural patterns of the special education class have been followed, during this period, he and his family were interviewed and what can be done at individual, family and community levels has been discussed. The case was evaluated in terms of general social work approach and the implementation of school social work and other alternative social work models in order to solve the problems of the T.K.'s attitude towards inward and outward behaviour.

Key words: Intellectual disabilities, School social work. Social work practice.

\section{Giriş}

Toplumun önemli bir unsuru olan bireyin yeteneklerini ve güçlerini toplumun yararına olacak şekilde kullanmasını sağlamak önemli ölçüde bireylerin sağlıkı bir biçimde yetiştirilmeleri ve iyi bir biçimde eğitilmeleri ile yakından ilgilidir. Günümüzde çağdaş eğitim yöntem ve teknikleri, bireysel farklılıkları dikkate alarak bireylere intiyaçları doğrultusunda hizmet vermek üzere planlanmaktadır. Dolayısıyla özel eğitime gereksinim duyan bireylerin topluma kazandırılması amacıyla onların mevcut zihinsel, bedensel ve sosyal beceri ve yeteneklerini geliştirecek biçimde eğitim gereksinimlerinin karşılanabilmesi önem kazanmıştır.

Sosyal hizmet, bireylerin, ailelerin ve toplumların sosyal işlevsellik hallerinin güçlendirilmesi ve ihtiyaç duyulduğunda yeniden şekillendirilmesi amacıyla gerçekleştirilen müdahaleler bütünüdür. Sosyal hizmet, çevresi içinde birey yaklaşımını mesleki odağı olarak görür.

Sosyal hizmet uzmanları; bireylerin başa çıkma kapasitelerini, sorun çözme becerilerini ve gelişimsel yeteneklerini ve özelliklerini güçlendirmek, insanlarla kaynaklar ve hizmetler arasında bağlantı kurmak, hizmet sundukları sistemlerin müracaatçılar açısından insan onuruna saygılı olup olmadıkları konusunda denetlemek ve sosyal politikaların geliştirilmesi sürecine katılmak için çalışırlar (Miley, O'Melia ve Dubois, 1998).

Sosyal hizmet uzmanları müracaatçı sistemine yönelik etkin uygulama yürütürken soruna neden olabilecek tüm unsurları dahil ederek bütüncül bir bakış açısı ortaya koymaktadır. Böylece sadece bireyin sorununa odaklanmaktan ziyade sosyal çevresini de hesaba katarak müdahaleler gerçekleştirip etkili sonuç alabileceklerinin 
farkındadırlar. Bundan hareketle bir yandan bireyle çalışılırken diğer yandan aile ve toplum boyutunda da çalışmalar yürüterek, kaynak yönetimi çerçevesinde bireyin sosyal etkililiğini arttırılabilmesini sağlamaktadırlar.

\section{Zihinsel Yeti Yitiminin Tanımı}

Zihinsel yeti yitimi olan çocuklar, gelişim sürecindeki zihinsel işlevlerde olağan gelişim gösteren çocuklardan dikkat çeken derecede geride olmakta, sosyal becerilerde ve uyumsal davranışlarda yetersizlik göstermektedirler. Günümüzde bütün meslek grupları tarafından kabul edilen ortak bir zihinsel yeti yitimi tanımı olmadığı görülmektedir. Konuya birden fazla meslek grubunun ilgi duyması, her meslek grubunun kendi odağından konuyu incelemesi, bunun yanında zihinsel yeti yitiminin karmaşık özellikleri bir arada barındırması, ortak bir tanım yapılabilmesini zorlaştırmaktadır. Literatürde ilk olarak zihinsel özür, zihinsel engellilik, zihinsel yetersizlik, zekâ geriliği gibi terimlerin kullanıldığı görülmektedir. Günümüzde kullanılmaya devam eden bu terimler, yerini yavaş yavaş anlıksal (entelektüel) yeti yitimine bırakmakta ve sağlıkçılar, eğitimciler, akademisyenler bu alanda çalışan diğer uzmanlar ve araştırma dergileri de anlıksal yeti yitimi terimini kullanmaya başlamaktadır.

Amerikan Psikiyatri Birliği (APA) tarafından yayınlanan ve ruhsal bozuklukların tanısı için açıklamalar, semptomlar ve diğer ölçütleri içeren DSM-5'de terim olarak zihinsel yeti yitimi kullanımakta ve nörogelişimsel bozukluklar başlığı altında yer almaktadır. Bu el kitabında zihinsel yeti yitimi, anlıksal (entelektüel, gelişimsel) yeti yitimi olarak da adlandırımaktadır. Anlıksal yeti yitimi hem anlıksal hem de uyumsal işlev eksikliklerini kapsayan, gelişimsel evre sırasında başlayan bir bozukluk olarak tanımlanmaktadır. Bu yeti yitimi için şu üç ölçütün karşılanması gerekmektedir:

- Klinik değerlendirmenin yapılması ve bireye özgü uygulanan bir zekâ ölçümü ile doğrulanması, tasarlama, akıl yürütme, yargılama, soyut düşünme, sosyal ve deneyimleme yoluyla öğrenme gibi anlıksal işlevlerde eksiklikler,

- Bireysel bağımsızlık kazanma, sorumluluk alabilme, sosyo-kültürel ölçüleri karşılamada sorun yaşama. Sürekli bir destek sağlanmadıkça ev ortamı, okul ve iş gibi farklı sosyal çevrelerde günlük yaşamın bir ya da birden çok etkinliğinde işlevselliğin kısıtlılığı,

- Anlıksal ve uyumsal eksikliklerin, gelişimsel evre sırasında başlamasıdır. 
Doll (1940), zihinsel yeti yitimi durumunu; zihinsel süreçlerde yaşıtlarından geride olma ve bunun bir sonucu olarak sosyal işlevsel yetersizlik, gelişim sürecinde duraksamaların yaşanması, olgunlaşmada gecikme, kalıtsal nedenlerin ya da hastalıkların bir sonucu olarak zihinsel yeti yitimi, kalıcı ve iyileşmesi mümkün olmayan bir durumun varlığı şeklindeki ölçütleri sıralayarak tanımlamıştır.

Bir başka tanıma göre zihinsel yeti yitimi; gelişim dönemi kapsamında genel itibariyle zihinsel işlevlerde önemli derecede sınıın altında olma, bunun yanı sıra uyumsal davranışlarda yetersizlik gösterme durumudur (Eripek, 2005; Tekinarslan, 2013, Turnbull, Turnbull, Shank, Smith ve Leal, 2002). Daha önce yapılan zihinsel yeti yitimi tanımlamalarının birçoğu bireyin kendi yetersizlikleri üzerine vurgulanmış, normalin altında zekâya sahip olma, uyumsal davranışlarda yetersiz olma gibi bireye bağlı yönler ele alınmıştır. Son yapılan tanımlamalarda ise bireyin yetersiz olduğu davranış/beceri/yetenek gibi yönlerden çok çevreden ne tür destek alması gerektiği konusu ön plana çıkartılmıştır.

Zihinsel yeti yitimi olan çocukların eğitimine yönelik amaçlar ve onlara kazandırılacak beceriler, davranışlar eğitim gereksinimleri bakımından birtakım farklılıklar göstermektedir. Eğitim gereksinimlerinin belirlenmesinde temel nokta zihinsel yeti yitimi olan çocuğa kendisinin yeterli hale gelmesine yardımcı olacak temel bilgi, beceri ve davranışların kazandırılabilmesidir. Zihinsel yeti yitimi olan çocukların eğitsel yerleştirilmelerinde, özel eğitim sınıfları ve kaynaştırma olarak iki temel yaklaşım söz konusudur. Bu yaklaşımlardan kaynaştırma eğitimi; bireyselleştirilmiş eğitim programlarıyla zihinsel yeti yitimi olan ve olmayan çocukların eğitsel ve sosyal yönden bütünleşmelerini sağlamak, aynı sınıf ortamında eğitim görmelerine olanak sağlanmasıdır. Özel eğitim sınıfları ise okul ve benzeri kurumlarda, özellikleri ve yetenekleri ayrı bir sınıfta eğitim görmeyi gerektiren, özel eğitim ihtiyacı olan öğrenciler için yeti yitiminin türleri ve eğitim performansları göz önünde bulundurularak, özel araç ve gereçler ile eğitim materyalleri sağlanarak oluşturulmuş sınıflardır.

\section{Zihinsel Yeti Yitiminin Nedenleri}

Zihinsel yeti eksikliğinin nedenleri değişik sınıflamalar içerisinde tartışılmaktadır. Zihinsel yeti eksikliğinin nedenleri oluş zamanına; doğum öncesi (Down sendromu, kromozomal bozukluklar, annenin kızamıkçık, frengi gibi geçirmiş olduğu hastalıklar, sigara ve alkol kullanımı, kurşun zehirlenmesi, geçirilmiş olan kazalar ve travmalar), doğum anında (bebeğin yeterli oksijen alamaması, beyin sarsılması ve beyin 
incinmesi), doğum sonrasında (çocuğun geçirmiş olduğu menenjit vb. hastalıklar, yeterli beslenmeme ve fiziksel istismara maruz kalma) ve oluş şekline (sosyal, tıbbi, davranışsal ve eğitsel) göre sınıflandırılmıştır (Amerika Zekâ Geriliği Birliği, 2002; Heward, 1996; Smith, 2007; Tekinarslan, 2013; Turnbull ve diğerleri, 2002; Turnbull, Turnbull ve Wehmeyer, 2007).

\section{Zihinsel Yeti Yitiminin Sınıflandırılması}

Zihinsel yeti yitimi, zekâ bölümü puanları ve bireylerin kavramsal, toplumsal ve uygulamalı alanlardaki süreçleri temel alınarak hafif, orta, ağır ve çok ağır şeklinde sınıflandırımaktadır ve Tablo 1'de sunulmaktadır (Amerika Zeka Geriliği Birliği, 1992; Amerikan Psikiyatri Birliği, 2013; Grossman; 1983).

Tablo 1: Zihinsel Yeti Yitiminin Ağırlık Düzeylerine Göre Sınıflandırılması

\begin{tabular}{|c|c|c|c|c|}
\hline $\begin{array}{l}\text { Ağırlık } \\
\text { Düzeyleri }\end{array}$ & $\begin{array}{l}\text { Zekâ Bölümü } \\
\text { Puanları }\end{array}$ & Kavramsal Alan & Toplumsal Alan & Uygulamalı Alan \\
\hline Hafif & $\begin{array}{l}50-55^{\prime} \text { ten yaklaşık } \\
70 \text { 'e }\end{array}$ & $\begin{array}{l}\text { Okul çocuklarında } \\
\text { ve erişkinlerde, } \\
\text { okuma, yazma } \\
\text { becerileri, sayısal } \\
\text { beceriler, zaman } \\
\text { ya da parayla ilgili } \\
\text { becerileri } \\
\text { kapsayan okulda } \\
\text { öğrenilen } \\
\text { becerilerde } \\
\text { güçlükler vardır ve } \\
\text { yaşla ilgili } \\
\text { beklentileri } \\
\text { karşılamak için bir } \\
\text { ya da birden çok } \\
\text { alanda desteğe } \\
\text { gerek vardır. }\end{array}$ & $\begin{array}{l}\text { Gelişmekte olan } \\
\text { yaşıtlarıyla } \\
\text { karşılaştırıldığında, } \\
\text { kişi toplumsal } \\
\text { etkileşimlerinde } \\
\text { olgun değildir, } \\
\text { yaşıtlarının } \\
\text { toplumsal } \\
\text { dışavurumlarını } \\
\text { tam olarak } \\
\text { algılayamaz. } \\
\text { Illetişimi, karşılıklı } \\
\text { konuşması ve } \\
\text { kullandığı dil, } \\
\text { yaşına göre } \\
\text { beklendiğinden } \\
\text { daha somut ya da } \\
\text { oldun değildir. }\end{array}$ & $\begin{array}{l}\text { Kişisel bakımında } \\
\text { yaşına uygun bir } \\
\text { işlevsellik } \\
\text { gösterebilir. } \\
\text { Yaşıtlarıyla } \\
\text { karşılaştırıldığınd } \\
\quad \text { a, karmaşık } \\
\text { günlük yaşam } \\
\text { görevleri için bir } \\
\text { ölçüde desteğe } \\
\text { gereksinebilir. }\end{array}$ \\
\hline Orta & 35-40'tan 50-55'e & $\begin{array}{l}\text { Bütün gelişimsel } \\
\text { süreçler boyunca, } \\
\text { kişinin kavramsal } \\
\text { becerileri, } \\
\text { yaşıtlarının hep } \\
\text { belirgin olarak } \\
\text { gerisinde } \\
\text { kalmıştır. Okul } \\
\text { öncesi } \\
\text { çocuklarda dil ve } \\
\text { okul öncesi }\end{array}$ & $\begin{array}{l}\text { Kişi, gelişimi } \\
\text { boyunca, toplumsal } \\
\text { ve iletişimsel } \\
\text { davranışlarında } \\
\text { yaşıtlarından } \\
\text { belirgin ayrımlar } \\
\text { gösterir. Konuşma, } \\
\text { toplumsal iletişim } \\
\text { için başlıca gereçtir, } \\
\text { ancak } \\
\text { yaşıtlarınkinden çok }\end{array}$ & $\begin{array}{l}\text { Kişi, bir erişkin } \\
\text { olarak, yemek } \\
\text { yeme, giyinme, } \\
\text { dışkılama ve } \\
\text { kişisel bakım gibi } \\
\text { kişisel } \\
\text { gereksinimlerini } \\
\text { karşılayabilir, } \\
\text { ancak bu } \\
\text { alanlarda kişinin } \\
\text { bağımsızlık }\end{array}$ \\
\hline
\end{tabular}




\begin{tabular}{|c|c|c|c|c|}
\hline & & $\begin{array}{l}\text { beceriler yavaş } \\
\text { gelişir. Okul } \\
\text { çocuklarında, } \\
\text { okuma, yazma } \\
\text { becerilerinde ve } \\
\text { sayısal } \\
\text { becerilerde } \\
\text { ilerlemede, } \\
\text { zamanı ve parayı } \\
\text { anlamada, okul } \\
\text { yılları boyunca bir } \\
\text { yavaşlık vardır ve } \\
\text { bunlar yaşıtlarıyla } \\
\text { karşılaştırıldığınd } \\
\text { a belirgin olarak } \\
\text { kısıtıdır. }\end{array}$ & $\begin{array}{l}\text { daha az karmaşıktır. } \\
\text { Ailesi ve } \\
\text { arkadaşlarıyla bağ } \\
\text { kurma, yaşamı } \\
\text { boyunca } \\
\text { arkadaşlıklarının } \\
\text { olması ve } \\
\text { erişkinlikte kimi } \\
\text { zaman sevgili } \\
\text { ilişkilerinin olmasıyla } \\
\text { belirli olmak üzere } \\
\text { ilişki kurma yeterliği } \\
\text { vardır. }\end{array}$ & $\begin{array}{l}\text { kazanabilmesi } \\
\text { için çok uzun bir } \\
\text { süre eğitim } \\
\text { verilmesi ve çok } \\
\text { zaman } \\
\text { harcanması } \\
\text { gerekir ve } \\
\text { anımsatıcılara } \\
\text { ihtiyaç duyulur. }\end{array}$ \\
\hline Ağır & 20-25’ten 35-40'a & $\begin{array}{l}\text { Kavramsal } \\
\text { beceriler sınırlı } \\
\text { kazanılmıştır. } \\
\text { Kişi, yazı dili ya } \\
\text { da sayılar, } \\
\text { nicelik, zaman ve } \\
\text { para gibi } \\
\text { kavramları } \\
\text { genelde çok az } \\
\text { anlar. Sorun } \\
\text { çözmelerine, } \\
\text { yaşamları } \\
\text { boyunca bakım } \\
\text { verenleri } \\
\text { yardımcı olur. }\end{array}$ & $\begin{array}{l}\text { Sözcük dağarcığı ve } \\
\text { dilbilgisi açısından } \\
\text { konuşma dili } \\
\text { oldukça sınırıdır. } \\
\text { Konuşma, tek tek } \\
\text { sözcüklerden ya da } \\
\text { deyişlerden } \\
\text { oluşabilir ve } \\
\text { güçlendirici araçlar } \\
\text { buna eklenebilir. } \\
\text { Konuşma ve } \\
\text { iletişim, gündelik } \\
\text { olaylar içinde, şimdi- } \\
\text { burada üzerine } \\
\text { odaklanmıştır. Bu } \\
\text { kişiler yalın } \\
\text { konuşmayı ve el-kol } \\
\text { hareketleriyle } \\
\text { iletişimi anlarlar. }\end{array}$ & $\begin{array}{l}\text { Kişi, yemekler, } \\
\text { giyinme, banyo } \\
\text { yapma ve } \\
\text { dışkılama gibi } \\
\text { bütün günlük } \\
\text { etkinlikler için } \\
\text { desteğe ihtiyaç } \\
\text { duyar. Her } \\
\text { zaman denetim } \\
\text { altında olmayı } \\
\text { gerektirir. } \\
\text { Kendisinin ya da } \\
\text { başkalarının } \\
\text { iyiliğini } \\
\text { ilgilendiren, } \\
\text { sorumluluk } \\
\text { isteyen kararları } \\
\text { alamaz. }\end{array}$ \\
\hline Çok Ağır & 20-25’ten aşağıya & $\begin{array}{l}\text { Kavramsal } \\
\text { beceriler } \\
\text { genellikle } \\
\text { simgesel } \\
\text { süreçlerden çok } \\
\text { fiziki dünyayı } \\
\text { kapsar. Kişi, } \\
\text { kendine bakım, iş } \\
\text { ve eğlenme- } \\
\text { dinlenme için } \\
\text { amacına yönelik } \\
\text { olarak nesneleri } \\
\text { kullanabilir. }\end{array}$ & $\begin{array}{l}\text { Kişinin, konuşma ve } \\
\text { el-kol hareketlerinin } \\
\text { simgesel iletişim } \\
\text { boyutunu anlaması } \\
\text { sınırıdır. Kendi } \\
\text { isteklerini ve } \\
\text { duygularını, büyük } \\
\text { ölçüde, sözel } \\
\text { olmayan, simgesel } \\
\text { olmayan iletişimle } \\
\text { dışa vurur. }\end{array}$ & $\begin{array}{l}\text { Kişi, günlük } \\
\text { bakım, sağlık ve } \\
\text { güvenlik gibi } \\
\text { alanlarda, bu } \\
\text { etkinliklerin bir } \\
\text { bölümüne kendisi } \\
\text { de katılabiliyor } \\
\text { olsa da, bütün } \\
\text { yönleriyle } \\
\text { başkalarına } \\
\text { bağımlıdır. }\end{array}$ \\
\hline
\end{tabular}




\section{Ekolojik Yaklaşım ve Okul Sosyal Hizmeti}

Ekolojik yaklaşım, yaşayan varlıklar arasındaki ilişkiler ve varlıklar ile çevrelerinin diğer görünümleri arasındaki ilişkilere odaklanmaktadır (Duyan, 2010; Yıldırım, 2007). Sosyal hizmet disiplininde ekolojik yaklaşım, insanlar ve çevreleri arasındaki etkileşimi ifade etmektedir ve profesyonel müdahalelerde bireylerin, grupların, ailelerin ve toplumların, çevreleri ile olan ilişkileri incelenmektedir (Duyan, 2010; Teater, 2015).

Ekolojik yaklaşım, birey ve diğer sistemler arasındaki karşılıklı etkileşimi temel almaktadır. Yaklaşımın, bireyin gereksinimleri ve çevresindeki sistemlerin özellikleri arasındaki uyumu ve baş etme mekanizmalarını geliştirme üzerine odaklandığını söylemek mümkündür. Ayrıca ekolojik yaklaşım çevresi içinde birey kavramsallaştırmasına vurgu yapmaktadır. Sosyal hizmet, bu kavramsallaştırma ile ilk olarak birey üzerinde odaklanarak, onun sorun çözme, başa çıkma ve gelişimsel kapasitelerini arttırmak için çalışmaktadır. İkinci olarak, sosyal hizmet, birey ve bireyin etkileşimde olduğu sistemler arasındaki ilişkiler üzerine odaklanarak, insanları gereksinim duyduğu kaynaklar, hizmetler ve fırsatlarla bağlantılandırmaktadır. Üçüncü olarak, sosyal hizmet, sistemlere odaklanarak, bireylerin gereksinimlerini daha etkin bir şekilde karşılayabilmeleri için kurumları harekete geçirmektedir (Duyan, 2010; Zastrow, 2016). Çevresi içinde birey kavramsallaştırılmasında; bireyin, aile, eğitim, sağlık, siyasal, istihdam, inanç, mal ve hizmetler ve sosyal hizmet gibi sistemlerle etkileşimi göz önünde bulundurulmalıdır (Zastrow, 2016).

Ekolojik yaklaşım, insan davranışını, gereksinimlerini ve sistemler arası ilişkilerdeki sorunları değerlendirmede sosyal hizmet mesleğine önemli katkılar sunmaktadır. Bu bağlamda bireyin çevresindeki sistemlerle olan etkileşimlerini geniş bir bakış açısıyla ele almak önem arz etmektedir. Sosyal hizmetin, eğitim alanına önem verdiğini ve bu alanda geniş bir uygulama perspektifi bulduğunu söylemek mümkündür. Sosyal hizmet uzmanı, ekolojik yaklaşım ile öğrencileri, onları çevreleyen sistemleri göz önüne alarak, okul, aile ve toplum düzeyinde etkinlikler gerçekleştirmektedir (Özkan ve Kılıç, 2014). Bu kapsamda mikro, mezzo ve makro düzeyde gerçekleştirilen müdahaleler; yeterli ve güvenli bir okul ortamı oluşturmak, içe dönük ve dışa dönük davranış problemlerini en aza indirgemek, akademik başarıyı yükseltmek, okul terklerini önlemek, okula etkin devamlılığı sağlamak, öğrenciler için bireysel danışmanlık, öğrenci aileleri için aile danışmanlığı sağlamak, aile ve okul personelinin bilinçlendirilmesi, aile ve okul arasındaki olumlu ilişkilerin geliştirilmesi, akran zorbalığı 
ile baş etmek şeklinde sıralanabilmekte ve bu müdahaleler öğrenciler, okul yönetimi, öğretmenler, aile ve toplum işbirliğinde yürütülebilmektedir (Bolley, 2015; Karataş, Gencer, Çalış ve Ege, 2014). Uygulama temelli bir meslek ve disiplin olan sosyal hizmet, okul sosyal hizmeti uygulamalarıyla özellikle özel eğitim ve zihinsel yeti yitimi alanına da önemli katkılar sunma olanağına sahiptir. Zihinsel yeti yitimi olan çocuklara ve ebeveynlerine yönelik savunuculuk yapmak, bilgilendirici ve farkındalık yaratıcı faaliyetler düzenlemek de okul sosyal hizmeti kapsamında değerlendirilebilmektedir (Dupper, 2013). Okul sosyal hizmeti, ekolojik yaklaşım kapsamında çocuğu çevresi içerisinde değerlendirerek ve bu doğrultuda geliştirilen faaliyet, çalışmalar ve uygulamalar ile çocuğun yüksek yararını gözeten bir eğitim anlayışının benimsenmesine yönelik bütüncül bir bakış açısı sunmaktadır (Karataş ve diğ., 2014).

\section{Çalışmanın Amacı ve Kapsamı}

Bu çalışmada ele alınan vaka T.K. on dört yaşında, ortaokul yedinci sınıfta kaynaştırma öğrencisidir. Eğitimine devam etmekteyken davranış problemleri göstermesi ve öğretmenlerinin onu bulunduğu sınıfta istememesi üzerine okulun özel eğitim sınıfına yönlendirilmiş ve eğitimine burada devam etmesi sağlanmıştır. T.K. sınırda mental kapasiteye (IQ:72) ve hiperaktiviteye sahiptir; aynı zamanda epilepsi hastasıdır. Bunlara ek olarak ergenlik döneminde olduğu için fizyolojik, duygusal ve sosyal gelişim gibi farklı boyutlarıyla baktığımızda; gelecekle ile ilgili kaygılar, çekingenlik, hayâl kurma, tedirgin ve huzursuz olma, yalnız kalmak isteme, çalışmaya karşı isteksiz olma ve çabuk heyecanlanma gibi davranış örüntülerini sergilemektedir (Koç, 2004). Ayrıntısıyla ele alınacak olay öyküsünde kaynaştırma öğrencisi olarak eğitimine devam etmekteyken özel eğitim sınıfına yönlendirilen ve sınırda mental kapasiteye sahip olan çocuğa nasıl bir sosyal hizmet müdahalesi uygulandığı; genelci sosyal hizmet yaklaşımı çerçevesinde vakanın, içe dönük ve dışa dönük davranış problemlerinin çözümlenmesi, aile, okul ve toplum düzeyinde çalışmalar yürütülerek okul sosyal hizmetinin uygulamaya geçirilmesi anlatılacaktır.

\section{Olgu ve Olayın Öyküsü}

Olgu, 2017 yılında Türkiye'de bir kent merkezindeki devlet okulunda gerçekleşmiştir. T.K. kaynaştırma öğrencisi olarak eğitimine devam etmekteyken davranış problemleri göstermesi nedeniyle ve öğretmenlerinin, kendisini bulunduğu sınıfta istememesi üzerine okulun özel eğitim sınıfına yönlendirilmiştir. Hem okul müdürü hem de rehberlik servisi, özel eğitim sınıfındaki öğretmenin aynı zamanda sosyal hizmet uzmanı olması nedeniyle süreci daha yakından takip edebileceğini düşünmüştür. 
Sosyal hizmet uzmanı, özel eğitim sınıfındaki T.K.'nın bilişsel ve davranışsal süreçlerini gözlemlemiştir. Bunun yanında kaynaştırma öğrencisi olduğu süre zarfında sık sık kendi sırasını terk etmesi, gürültülü ve düzensiz olması, öğretmenlerinin yönergelerine uymaması ve sürekli sınıfı terk etmek istemesi gibi sınıf içi davranış problemleri gösterdiğini hem rehberlik servisi hem de öğretmenleri ile yaptığı görüşmeler aracılığıyla öğrenmiştir. Bu tür davranış problemleri göstermesi nedeniyle öğretmenlerinin birçoğu tarafından 'sınıfın sorun çıkaranı' olarak ifade edilmiştir. Aynı zamanda T.K. başka öğrencilerle dalga geçme, onları tehdit etme ve onlara yönelik fiziksel şiddet uygulama gibi zorbalık davranışlarını sergilemektedir. Akranlarını şiddet göstererek tehdit etmesi, sınıf değişikliği nedeniyle yakın arkadaşlarıyla ilişkilerinin kesilmesi ve bunun sonucunda izolasyon yaşaması, birçok öğrenci tarafından kendisiyle dalga geçilmesi ya da dalga geçildiğini düşünmesi, okula olan ilgisinin düşük olması, diğer öğrenciler tarafından 'farklı' olarak tanımlanması gibi durumlar süreç boyunca gözlemlenmiştir.

Eğitimine devam ettiği süre boyunca içe dönük ve dışa dönük davranış problemleri devam eden T.K.'nın, okula bıçak, muşta vb. aletler getirdiği, en son olarak da gizlice boş olan bir sınıfa girip kalem kutusu içinde olan parayı almış olduğu okulun kameraları aracılığıyla tespit edilince ailesi görüşmeye çağrılmıştır. Ailenin geliş nedeni; T.K.'nın davranış ve uyum problemlerinin olması ve ayrıca kendisine ait olmayan bir parayı alması nedeniyle disiplin sürecinin başlamasıdır.

\section{Biyo-Psiko-Sosyal ve Ekonomik Değerlendirme ve Sosyal Hizmet Müdahalesi}

Ailelere yönelik çalışmalar gerçekleştirmek sosyal hizmet uygulaması ve müdahalesinin önemli bir boyutudur. Aile ilişkilerinin değerlendirilebilmesi tüm aile bireylerini anlamak ile yakından ilgilidir. Her bir aile bireyi, büyük aile sisteminin bir alt sistemi işlevini görmektedir. Bu nedenle, aile üyelerini ilgilendiren ve etkileyen herhangi bir durum aynı zamanda tüm aileyi ve diğer aile üyelerini de etkileyebilmektedir. Ailenin bir başka önemli özelliği, üyelerinden birisi ile mikro düzeyde sosyal hizmet uygulaması çerçevesinde çalışırken tüm aile bireylerine de müdahale etmenin gerekli olmasıdır. Aile sisteminin güçlü kalabilmesi, üyelerinin fiziksel, duygusal ve sosyal açıdan iyilik hali ile doğrudan ilişkilidir. Tüm aile ile çalışırken uzmanın görevi, aile bireylerinin kendi bakış açılarından sorunu değerlendirebilmek, bütün aile üyeleriyle etkileşim ve iletişime geçerek tarafsızlığını korumalıdır. Yeti yitimi olan bireyler ve aileleri ile sosyal hizmet uygulamaları genellikle görüşmeler yoluyla gerçekleşmektedir. İlgili vaka, sosyal hizmetin planlı müdahale 
aşamaları çerçevesinde (tanışma/bağlantı kurma, ön değerlendirme, planlama, uygulama, son değerlendirme, sonlandırma ve izleme/bağlantıyı kesme) anlatılacaktır. Vaka çalışması 2017 yılı Ocak-Haziran arasındaki altı aylık bir süreci kapsamaktadır. T.K., aile üyeleri ve öğretmenler ile yapılan görüşmeler Rehberlik Servisi'nin bulunduğu odada gerçekleştirilmiş, her bir aile üyesi ve öğretmenlerle ayrı ayrı görüşülmüştür. Vaka sürecinde, T.K. ile birebir olarak toplamda 50 görüşme, aile üyeleri ile toplamda 24 görüşme, okuldaki matematik, Türkçe, resim, müzik, beden ve rehberlik öğretmenleri ile toplamda 15 görüşme yapılmıştır.

\section{Tanışma/Bağlantı Kurma Aşaması}

Tanışma/bağlantı kurma, sosyal hizmet uzmanlarının kendilerini soruna yönlendirdiği ve sorunla ilgili kişilerle iletişim ve ilişki kurduğu bir zaman dilimidir. Mikro, mezzo ve makro düzeyde değişiklik gerçekleştirebilmek için müracaatçılarla veya hedef sistemlerle ilişki kurmak ve uyumlu ilişkiler geliştirmek gerekmektedir (Duyan, 2010; Turan, 2012). Sosyal hizmet uzmanı ve aile bireyleri arasında güven ilişkisinin kurulması, aile bireylerinin var olan sorun hakkında konuşabilmeleri için umut ve iyilik atmosferinin sağlanması önem arz etmektedir (Duyan, 2010; Turan, 2012; Zastrow, 1999).

T.K.'nın özel eğitim sınıfına yönlendirilmesi ve özel eğitim sınıfındaki öğretmenin aynı zamanda sosyal hizmet uzmanı olması nedeniyle süreç daha yakından takip edilmiştir. Sosyal hizmet uzmanı, özel eğitim sınıfındaki T.K.'nın bilişsel ve davranışsal süreçlerini incelemiştir. Sık sık kendi sırasını terk etmek istemesi, gürültü çıkarması, sınıftaki diğer arkadaşlarına bağırması, öğretmenlerinin yönergelerine uymak istememesi ve sürekli sınıfı terk etmek istemesi gibi sınıf içi davranış problemleri gösterdiğini yakından gözlemlemiştir. Bunlarla beraber T.K. arkadaş çevresinde tanınan biridir. Fakat arkadaş ilişkileri olumsuzdur. T.K.'nın sık sık arkadaşlarına yönelik fiziksel şiddet ve sözel şiddet uyguladığı gözlemlenmiş ve bu durum diğer öğretmenleri tarafından da dile getirilmiştir. Dikkat Eksikliği ve Hiperaktivite Bozukluğu (DEHB) nedeniyle kullanması gereken ilaçları kullanmadığında bu tür davranış problemlerini daha fazla gösterdiği gözlemlenmektedir. Davranış problemleri ve gözlemlenen uyum sorunları, arkadaşlarına yönelik uyguladığı fiziksel ve sözel şiddet T.K. ile konuşulmuştur. T.K. kendi sınıfından ve arkadaşlarından ayrılmasına çok üzüldüğünü, öğretmenlerinin kendisini istemediğini ve bunu açıkça dile getirdiklerini söylemiş ve bu nedenle kızgın olduğunu hem sözel hem de davranışsal olarak ifade etmiştir. 
Çalışılan vakada, sorunu doğasını ve kapsamını anlayabilmek ve buna yönelik bir çözüm geliştirebilmek amacıyla aile bireylerinin kendi bakış açılarından sorunu değerlendirebilmesine zemin hazırlanmıştır ve anne, üvey baba ve üvey kardeş ile görüşmeler gerçekleştirilmiştir. Anne ile yapılan ilk görüşmede, çalışmadığı, ikinci bir evlilik yaptığı ve boşandığı eşinin ceza infaz kurumunda hükümlü olduğu bilgisi alınmıştır. T.K'nın, annenin ilk evliliğinden istenilerek doğduğu öğrenilmiştir. Annenin hamilelik döneminde sigara içtiği ve bununla beraber sağlıksız beslendiği bilgisi de alınmıştır. Doktorların, genetik faktörlerin yanında, T.K.'nın yeti yitiminin ikincil bir nedeni olarak annenin sağlıksız beslenmesinin olabileceğini ifade ettikleri aktarılmıştır. Hamilelik döneminin sıkıntılı geçtiği ve bunun nedeninin de boşanmış olduğu eşinin olduğu öğrenilmiştir. Evlilikleri süresince eski eşinin kendisine fiziksel ve duygusal şiddet uyguladığını ifade etmiştir. Ayrıca boşanmış olduğu eşinin T.K. doğduktan çok kısa bir süre sonra işlediği bir suçtan dolayı tutuklanarak ceza infaz kurumuna girdiğini aktarmıştır. Yapılan görüşmelerde annenin T.K.'ya öz babasının öldüğünü söylediği bilgisi alınmıştır. T.K.'nın anneannesinin bazı zamanlarda öz babanın ölmediğini dile getirmesi nedeniyle evde huzursuz bir ortam oluştuğu da öğrenilmiştir. Anneye T.K'nın epilepsi hastalığı ve DEHB için kullanması gereken ilaçları kullanıp kullanmadığı, yeterli dozlarda verilip verilmediği sorulmuş; anne ilaçların takibini yapamadığını ve düşürülen DEHB ilaç dozunun olası sonuçlarını hem öğretmenleriyle hem de okulun Rehberlik Servisi ile paylaşmadığını belirtmiştir. Anne, davranış problemleri için T.K'yı psikiyatra götürdüğünü ifade etmiş fakat T.K.'nın ergenlik dönemine girdiği için olumsuz davranışlar göstermesinin normal olacağı bilgisinin psikiyatr tarafından kendisine aktarıldığını belirtmiştir. Anne, yaramazlık yaptığı ve söz dinlemediği zamanlarda T.K.'ya yönelik fiziksel şiddet uyguladığını aktarmıştır. T.K. anne ve üvey babayla sürekli çatışma halindedir. T.K.'nın göstermiş olduğu olumsuz davranış ve tutumların anne ile üvey baba arasında çatışmaya neden olduğu, evde tartışmaların yaşandığı bilgisi alınmıştır. T.K.'nın uyku problemleri olduğu, uykusundan korkarak ve aşırı terleyerek uyandığı bilgisi annesi tarafından söylenmiştir. Bu durumun bir nedeni olarak ebeveyn çatışmasının varlığının söz konusu olabileceği düşünülmüştür.

Anne yeni bir evlilik yapmış ve yeni evlendiği eşinden bir oğlan çocuğu daha bulunmaktadır. Aile üyelerinden üvey baba ve üvey kardeş ile yapılan ilk görüşmede T.K.'nın üvey kardeşi ve üvey babası tarafından T.K. ile ilişkilerinin olumlu olduğu aktarılmıştır. Üvey babanın bir ayakkabı mağazası olduğu, aylık gelirinin evdeki tüm intiyaçları karşıladığı bilgisi alınmıştır. Bununla beraber üvey baba, T.K.'nın 
intiyaçlarının alınan yeti yitimi maaşı ile karşılandığını belirtmiştir. Üvey kardeşi T.K.'yı çok sevdiğini dile getirmiştir. Fakat T.K.'nın üvey babasından korktuğu hem anne hem de üvey baba tarafından dile getirilmiştir. Anne ve üvey babası, T.K.'nın davranış problemlerine gerekçe olarak üvey babasının erkek kardeşini göstermiş ve onunla olan ilişkisi nedeniyle bu tür şiddet eğilimleri gösterdiğini ifade etmiştir. Üvey amcanın ağır ithamlar içeren kelimeleri çok fazla kullandığı, sık sık şiddet olaylarına karıştığı, bu şiddet olaylarının birçoğunda T.K.'nın da yanında olduğu bilgisi hem anne hem de üvey babasıyla yapılan görüşmelerde alınmıştır. Bununla beraber T.K.'nın kendisine ait olmayan bir parayı alması anne ve üvey babasını çok şaşırtmış, evden okula gönderirken 5 TL harçlık verdiklerini özellikle belirtmişlerdir.

\section{Ön Değerlendirme Aşaması}

Ön değerlendirme, sorunun ne olduğunun ve sorunun ortaya çıkmasında etkili olabilecek faktörlerin neler olabileceğinin, hangi durumların değişmesi gerektiğinin iyi bir biçimde anlamanın amaçlandığı ya da bir sorunun çözülmesi ya da en aza indirilmesi için doğasını, nedenini, gelişimini ve yönünü belirleme sürecidir (Barker, 1999; Duyan, 2010; Turan, 2012).

Ön değerlendirme süreci, bireyin ve ailenin karşılaştığı sorunlar, aile üyelerinin katıımı, aile içi işleyişinin nasıl olduğu ve ailede iletişimin nasıl kurulduğu, ailede intiyaçların karşılanıp karşılanmadığı, bireylerin ve ailelerin ekolojik çevresi (arkadaşlar, aileler, okul, iş, dini kurumlar ve sağlık hizmetleri vd.) ile olan ilişkilere yönelik bir değerlendirmeyi kapsamaktadır (Collins, Jordan ve Coleman, 2007; Duyan, 2010; Turan, 2012). Çalışılan vaka özelinde, T.K.'nın eğitimine devam ettiği süre boyunca içe dönük ve dışa dönük davranış problemleri göstermektedir. Okula bıçak, muşta vb. aletler getirmekte, gizlice boş olan bir sınıfa girip kalem kutusu içinde olan parayı almış olduğu okulun kameraları aracılığıyla tespit edilmiştir. T.K.'nın bu tür davranış problemleri göstermesi ailesiyle görüşmeler gerçekleştirilmesini gerekli kıımıştır. Ayrıca T.K.'nın okul içinde ve dışında yaşadığı sorunlar ebeveynler arasında çatışma yaşanmasına neden olmaktadır. Ailenin ekonomik olarak herhangi bir sıkıntısının olmadığı yapılan görüşmelerde aile üyeleri tarafından dile getirilmiştir. Bununla beraber ailenin diğer yeti yitimine sahip çocuğu olan aileler ile ilişkiler kuramadığı, yeti yitimi konusunda yeterli düzeyde bilgi sahibi olmadığı saptanmıştır.

\section{Planlama Aşaması}

Planlama, sorun çözme sürecinde neyin yapılması gerektiğinin belirlenmesidir. Planlama aşamasında; müracaatçıyla birlikte çalışma, sorunları önceliklerine göre 
sıralama, sorunları gereksinimler şeklinde tanımlama, her bir gereksinim için müdahale düzeyini değerlendirme, temel amaçları oluşturma, hedefleri belirleme ve sözleşme hazırlama olmak üzere alt basamakları bulunmaktadır (Duyan, 2010; KirstAshman ve Hull, 1999).

Yeti yitimi olan bireyler ve aileleri ile yürütülen çalışmalarda sosyal destek kavramı önem arz etmektedir. Sosyal destek bireylerin stresli bir durumun varlığında o stresle başa çıkmasını kolaylaştıran, bireylere sorun çözmede ve çözüm yolları bulmada yardımcı olan bir mekanizmadır (Caplan ve Killilea, 1976; Karataş, 2013). Sosyal destek mekanizmaları; duygusal sosyal destek (bireyin sevildiğini hissetmesi ve insan olarak değerli bulunduğuna yönelik bir algısının oluşmasına yol açan davranışlar), bilgisel sosyal destek (hasta ya da yeti yitimi olan bireye kendisine nasıl yardım edebileceği konusunda farklı bir görüş kazandırmak) ve araçsal sosyal destek (çocuklarla ilgilenme, ev içindeki ve dışındaki sorumlulukları üstlenme) şeklinde sınıflandırılabilmektedir ve bu mekanizmalar zaman zaman birbirini kapsayan özellikler taşıyabilmektedir (Bloom, 1982; Demirbilek; 2013; Neuling, 1988; Tufan, 1994). Yeti yitimi olan bireyler için gerekli olan sosyal desteği aile üyeleri, yakın arkadaş çevresi ve meslek sahibi kişilerin sağladığını söylemek mümkündür. Sosyal hizmet uzmanları meslek sahibi kişiler arasında yer almaktadır ve hem yeti yitimi olan bireylere hem de ailelerine destek olmaktadır.

Planlama aşamasının olumlu bir şekilde gerçekleşebilmesi için okul sosyal hizmeti perspektifinden yaklaşımasının uygun olacağı düşünülmüştür. Okul sosyal hizmeti; okul ortamında yaşanan geniş kapsamlı problemleri ele almak, ekolojik bakış açısı ile öğrencilerin içinde bulundukları gelişim dönemi, aile ve yaşam koşulları nedeniyle yaşadıkları sorunların çözümü, gereksinim duyulan hizmetlerden yararlanmaları ve böylece eğitim etkinliklerini başarı ile sürdürmelerini sağlama gibi hizmetleri yürütmektir (Dupper, 2013; Nadir ve Aktan, 2016). T.K. ve aile üyelerine yönelik gerçekleştirilen ön değerlendirmeler ve görüşmeler sonucu; öncelikli olarak içe dönük ve dışa dönük davranış problemlerinin azaltılması ve çözümlenmesi amacıyla T.K.'ya yönelik psiko-sosyal destek sağlanması, ailesiyle birlikte çalışma yapııması, sonrasında ise T.K.'ya yönelik dışlayıcı ve suçlayıcı tutum ve davranışların değiştirilmesi ve çözümlenmesi için öğretmenler ile çalışılması, yeti yitimine yönelik okuldaki tüm ailelerin ve öğrencilerin bilgilendirilmesi, bu konuda farkındalık yaratıcı etkinliklerin yapılmasının uygun olacağı düşünülmüştür. 


\section{Uygulama Aşaması}

Müracaatçıların ve sosyal hizmet uzmanlarının amaçlarını gerçekleştirmek için birlikte hazırladıkları planın hayata geçirilmesi, uygulama aşamasını oluşturur. Uygulama sürecinde meydana gelen gelişmenin sürekli izlenmesi, mikro, mezzo ve makro düzeyde değerlendirilmesi önem taşımaktadır (Duyan, 2010; Turan, 2012).

Okulun son dört haftasında olunduğu için T.K.'nın sınıfı tekrar değiştirilememiştir ancak bunun yerine bulunduğu sınıf ortamına uyum sağlaması ve hem arkadaşlarıyla hem de öğretmeni ile olumlu ilişkiler kurması sağlanmıştır. T.K.'nın kendisine ait olmayan bir parayı alması hususunda, öğretmenleri ve okul müdür yardımcıları, anne ve babası ile bir toplantı düzenlemiş ve sonrasında konu hakkında T.K. ile bir görüşme gerçekleştirilmiştir. T.K. başka bir sınıfa girip para almadığını belirtmiştir. Okulun her katında bulunan güvenlik kamerası kayıtlarının kendisine izletilmesi sonrasında, başka bir sınıfa girip kendisine ait olmayan bir parayı aldığını kabul etmiştir. T.K., sosyal hizmet uzmanı, okul müdür yardımcıları ve Rehberlik Servisi kendisiyle görüşerek, bu tür bir davranışın yanlış olduğunu ve okul kurallarına aykırı olduğunu, disiplin cezası alabileceğini belirtmişlerdir. T.K. yapılan görüşme sonrası özür dilemiş ve bu durumun bir daha tekrarlanmayacağı hususunda söz vermiştir. Süreç boyunca günlük takipler yapılarak öğretmenlerinden eğitsel, sosyal ve davranışsal olarak geri bildirimler alınmıştır. Bununla beraber T.K.'ya sosyal hizmet uzmanı tarafından uygulanan Temel Kabiliyetler Testi ışığında, onun ilgi ve yetenekleri hakkında bilgiler edinilmiş ve bu doğrultuda sosyal ve eğitsel etkinliklere yönlendirilmesi sağlanmıştır. T.K. futbol ve basketbol oynamayı çok sevmektedir ve okul takımında olmak istemektedir. Bu kapsamda T.K.'nın beden eğitim öğretmeni ile görüşülmüş düzenli aralıklarla hem basketbol hem de futbol antrenmanları yapması için desteklenmiştir.

Aile dinamiklerinin gelişmesi, ebeveyn ve çocuk etkileşiminin olumlu hale getirilmesi için sosyal hizmet uzmanı, şubat ayında, okuldaki özel eğitim öğretmenleri ile işbirliğinde, ilk olarak öğretmenlere ve sonrasında özellikle yeti yitimi olan çocukların ailelerine, yeti yitimi ve özel eğitim kapsamında özel eğitim kurumları, sağlık kurumları, kaynaklar ve yeti yitiminin kavramları, gelişimi ve bireysel ve sosyal yaşamdaki sonuçları hakkında bir seminer düzenlemiştir. Bu seminer, yeti yitimi olan çocukların ailelerinin birbiri ile tanışma fırsatı yakalamasını sağlamış ve olumlu ilişkiler kurmalarına olanak vermiştir. Okuldaki öğretmenlerin ve aynı zamanda öğrencilerin özel eğitim, zihinsel yeti yitimi konuları hakkında bilgilendirilmesi için etkinlikler gerçekleştirilmiştir. Sosyal hizmet uzmanı, mart ayında, okuldaki müzik 
öğretmenlerinin desteği ile bir müzik festivali düzenlemiş, yeti yitimi olan çocukların ve onların ailelerinin katılımını sağlamıştır. Okuldaki resim öğretmenleri ile görüşülerek, nisan ayında, yeti yitimi olan çocukların çizdikleri resimlerin bir sergi ile sunulması sağlanmış ve okuldaki tüm çocukların bunları görerek farkındalık oluşturması amaçlanmıştır. 10 Mayıs Engelliler Haftası'nda, sosyal hizmet uzmanı, okuldaki beden eğitimi öğretmenlerinin desteği ile yeti yitimi olan çocukların futbol, basketbol ve koşu sporlarının olduğu bir turnuva düzenlemiştir.

Öğretmenlerin T.K.'ya yönelik gerçekleştirdikleri dışlayıcı ve suçlayıcı tutumlar hakkında görüşmeler gerçekleştirilmiştir. Özellikle Türkçe ve matematik öğretmenleri ile yapılan görüşmelerde multidisipliner çalışmanın gerekliliği vurgulanarak, herhangi bir sorunun varlığında, öğrenciyi dışlamanın ve/veya suçlamanın onun üzerinde ciddi travmatik sonuçlar yaratabileceği belirtilmiş ve Rehberlik Servisi'nin, özel eğitim öğretmenlerinin ve okul yönetiminin sürece dahil edilmesi gerektiği konuşulmuştur. Ayrıca öğretmenlerin, okul çapında yeti yitimi kapsamındaki etkinliklere katılımları sağlanmıştır.

Anneye ilaçların takibini doğru bir şekilde yapması gerektiği söylenmiş ve düzenli olarak hem T.K.'nın psikiyatrı ile hem de Rehberlik Servisi ile iletişimde kalması gerektiği hatırlatılmıştır. Annenin her konuda çocuğuna karşı dürüst olması söylenmiştir. Çocuğuna fiziksel şiddet uygulamasının sonucu olarak T.K.'nın da çevresindeki akranlarına şiddet uyguladığı ifade edilmiştir. T.K.'nın her türlü şiddet ortamından uzak kalabilmesi, olumlu bir benlik ve kimlik geliştirebilmesi, çevresi ile uyum içinde olabilmesi amacıyla üvey amcasıyla vakit geçirmemesi önerilmiştir. Bu kapsamda hem anne hem de baba ile görüşmeler gerçekleştirilmiş ve aile içi dinamiklerin yeniden düzenlenmesi adına bir psikoloğa yönlendirilmişlerdir.

\section{Son Değerlendirme Aşaması}

Son değerlendirme, sosyal hizmet müdahalesinin amaca ulaşıp ulaşmadığının belirlendiği bir aşamadır. Amaçlara ve hedeflere ulaşmak için kullanılan araçların, gerçekleştirilen her türlü faaliyetin gözden geçirildiği, beklenenlerin gerçekleşip gerçekleşmediğinin saptanır hale getirildiği bir süreçtir (Duyan, 2010; Turan, 2012).

T.K.'nın kaynaştırma sınıfında eğitim görmekteyken öğretmenleri tarafından ayrımcılığa uğraması, öğretmenlerinin onu bulunduğu sınıfta istememeleri güvensiz ilişkiler kurulmasına neden olmuştur. Öğretmen desteğinin önemi göz önünde bulundurulduğunda, T.K.'nın özel eğitim sınıfına yönlendirilmesi sürecinde özel eğitim öğretmeniyle olumlu ilişkiler geliştirmesi sağlanmıştır. T.K. öğretmenini rol model 
alarak öğretmen olmak istediğini birçok kez dile getirmiş ve özdeşim kurmaya başlamıştır. Illk görüşmeden itibaren planlanan ve uygulamaya geçirilen eğitsel ve sosyal faaliyetler sosyal hizmet uzmanı tarafından bir program doğrultusunda sürdürülmüştür. T.K.'nın öğretmenine güven duymaya başladığı ve davranış problemlerinde bir azalma olduğu gözlemlenmiştir.

Aile üyelerinin sürece aktif bir şekilde katılım göstermesinin sağlanması olumlu sonuçlar vermiştir. Anne ve üvey baba yeti yitimi konusunda birçok kez bilgilendiklerini ifade etmiş ve sosyal hizmet uzmanlarının yönlendirmeleriyle Rehberlik Araştırma Merkezi, Özel Eğitim ve Rehabilitasyon Merkezleri'ni sık sık ziyaret etmişlerdir. Anne ve üvey babanın aile içi dinamiklerin yeniden düzenlenmesi, kendi aralarındaki iletişimin daha olumlu hale getirilmesi amacıyla psikoloğa yönlendirilmeleri olumlu sonuçlar vermiş, hem anne ve üvey babadan hem de psikologdan pozitif bir yönde değişimin olduğuna dair geri bildirimler alınmıştır.

Öğretmenlerle, T.K.'ya yönelik gerçekleştirdikleri dışlayıcı ve suçlayıcı tutumlar hakkında görüşmeler gerçekleştirilip, okul çapında yeti yitimi kapsamındaki etkinliklere katıımları sağlandıktan sonra tutum ve davranışlarında olumlu yönde değişimler gözlemlenmiştir.

\section{Sonlandırma/Bağlantıyı Kesme Aşaması}

Sonlandırma/bağlantıyı kesme, sosyal hizmet uzmanları ile müracaatçılar arasındaki çalışma ilişkisinin sonlandırılığı, müracaatçı sistemi ile kurulan profesyonel ilişkinin kesildiği bir aşamadır (Duyan, 2010; Kirst-Ashman ve Hull, 1999). T.K.'nın ve aile üyelerinin gereksinim duyduğu kaynak ve hizmetlerden yararlanması, duygu, düşünce ve davranışlarında olumlu değişmelerin gerçekleşmesi sağlanmıştır. T.K.'nın içe dönük ve dışa dönük davranış problemleri en aza indirgenmiş, arkadaşları ve öğretmenleri ile olumlu ilişkiler kurmaya başlamıştır. Aile üyeleri arasındaki ilişki olumlu yönde değişmeye başlamıştır. Ayrıca aile üyelerinin yeti yitimi konusunda bilinçlenmesi ve diğer aileler ilişki kurması sağlanmıştır. Okuldaki birçok öğretmen ve öğrencinin yeti yitimi özelindeki etkinliklere katılması, okul atmosferinde olumlu yönde bir değişim gerçekleştirmiştir. Bu kapsamda vaka süreci olumlu bir şekilde sonlandırılmıştır.

\section{İzleme Aşaması}

İleme, müdahalenin tamamlanmasından sonra müracaatçının içinde bulunduğu durumun biyo-psiko-sosyal açılardan tekrar incelenmesini kapsamaktadır (Duyan, 
2010; Turan, 2012). İzlemenin temel amacı, müracaatçıların müdahale sürecindeki kazanımlarını koruyup korumadığını belirlemektir (Duyan, 2010). Okul döneminin bitmesi ve yaz tatiline girilmesine kadar olan 1 aylık gibi bir süreçte hem T.K. hem de aile üyeleri izlenmiştir. Vaka çalışması boyunca elde edilen kazanımların devam ettiği, herhangi bir sorunun varlığında, bunun Rehberlik Servisi ve öğretmenleri ile paylaşıldığı, çözüm üretilmeye çalışıldığı gözlemlenmiştir. T.K. ile sık sık görüşülmüş, aile üyeleri ile de hafta da bir kez bir araya gelinmiştir.

\section{SONUÇ}

Bireyin ailesinde ya da sosyal çevresinde yaşadığı birçok olay kendisinde çaresizlik, aşırı kızgınlık, bunalım, şiddet uygulama gibi içe dönük ve dışa dönük davranış problemleri göstermesine neden olarak bireyin topluma uyum sağlamasını olumsuz yönde etkilemektedir. Bireyin bu davranış problemlerinin iyi yönetilebilmesi ve çözüme ulaştırılması yine bireyin güçlenmesine, başa çıkma stratejilerini geliştirmesine ön ayak olmaktadır. Kaynakların danışanın yararına olacak bir biçimde düzenlenmesi, ekolojik bir perspektifle sürece yaklaşılması, bireyin sosyal işlevselliğinin güçlendirilmesi gibi durumların göz önüne alınarak planlı müdahale sürecinin oluşturulması meslek elemanı açısından önem arz etmektedir.

Makalede ele alınan vakada sosyal hizmetin bilgi, beceri ve değer boyutu dikkate alınmıştır. Bu kapsamda soruna neden olan olayla ilgili bilgi toplama, analiz etme ve birey ve aile ile çalışılarak aktif bir süreç yönetilmiştir. Bu nedenle; eğitimine devam ettiği süre boyunca içe dönük ve dışa dönük davranış problemleri devam eden T.K.'nın, okula bıçak, muşta vb. aletler getirdiği, en son olarak da gizlice boş olan bir sınıfa girip kalem kutusu içinde olan parayı almış olduğu okulun kameraları aracılığıyla tespit edilmesi sonrasında hem kendisi hem de çevresi hakkında genelci sosyal hizmet yaklaşımı doğrultusunda, çocuğun yüksek yararı gözetilerek bütüncül bir değerlendirme yapılmaya çalışılmıştır. T.K. ile yapılan ilk görüşmeden itibaren içinde bulunduğu psiko-sosyal durumu, duygusal tepkileri anlaşılmaya çalışılmıştır. Değerlendirmeler sonrasında ilgi alanları ve intiyaçları tespit edilmiş hem okul boyutunda hem de aile boyutunda güvenli bir ortam oluşturulmaya çalışılmıştır. T.K.'nın annesinin ve üvey babasının sürece dahil edilerek özel eğitim, zihinsel yeti yitimi gibi konular hakkında bilgilenmesi adına etkinliklere ve eğitimlere katılımları sağlanmıştır. Anne, baba ve T.K. arasındaki iletişim okul ortamında ve sonrasında izlenmiş, aileye gerekli rehberlik ve danışmanlık hizmeti verilmiştir. Bu sonuçlar doğrultusunda özel eğitime gereksinimi olan çocukların ailelerine; zihinsel yeti yitimi 
ve özel eğitim konularında çocuk kadar kendilerinin de profesyonel desteğe intiyacı olduğu hatırlatılmalıdır.

Zihinsel yeti yitimi olan çocuğun sağlıklı büyütülmesi ve gelişim gösterebilmesi için aile içindeki rollerin yeniden yapılandırılması ve aileye bu kapsamda destek olunması, ailenin yaşadığı problemler dikkate alınması, ailelerin eğitimi ve rehabilitasyonunda sosyal hizmet kurumlarından yararlanmalarının sağlanması, konu hakkında konferans, seminer verilmesi için çalışmalar yürütülmesi, zihinsel yeti yitimi olan çocukla çalışırken asıl amacın çocuğun mümkün olduğunca bağımsız olarak kendi kendine yeterli duruma gelmesi, ailelerin buna yönelik bilgilendirilmesinin gerekliliğini göz önünde bulundurmak önem arz etmektedir.

Birey ve aile ile çalışmanın yanı sıra zihinsel yeti yitimine yönelik sosyal hizmet uygulamaları makro boyutta topluma yönelik çalışmaları da içermektedir. Sosyal hizmet uzmanları; yeti yitimi konusunda toplumu ve kamu görevlilerini bilinçlendirmek, ailelerinin birlikte daha etkin ve bilinçli bir mücadele vermeleri için örgütlenmelerini teşvik etmek, yeti yitimine sahip bireylere yönelik yanlış algı, tutum ve önyargıların değiştirilmesine yönelik çalışmalar yapmak, bireylerin boş zamanlarını değerlendirici etkinlikler oluşturmak, yeti yitimi alanında araştırmalar yapmak, sürdürmek ve bu araştırmaların sonuçlarını ilgili hizmet sağlayıcılarına bildirmek, yeti yitimine sahip bireylere yönelik pozitif ayrımcılık sağlanması ve bunlarla ilgili yasal düzenlemelerin yapılması konusunda kamuoyu oluşturmak gibi işlevlere sahiptir (Arıkan, 2001; Cankurtaran-Öntaş, 2001; Demiröz, 2001; Erkan ve Koçyıldırım, 1996; Gibelman, 1995; Küçükkaraca, 2001; Mackelprang ve Salsgiver, 1999).

Okul, öğrencilerin oldukça fazla zaman geçirdikleri önemli bir sosyal kurum niteliği taşımaktadır. Okulda geçirilen zaman öğrencinin hem okul hem de diğer sosyal sistemlerle ilgili yaşadığı sorunların belirlenmesi ve değerlendirilmesi açısından önem taşımaktadır. Okul sosyal hizmeti, odağına çocuğu yerleştirmekle birlikte, çocuğu çevreleyen diğer sistemleri ve yapıları inceleyerek sorunları önlemede ve çözmede önemli müdahale yöntemleri geliştirebilmektedir. Ekolojik yaklaşımın sunduğu çevresi içinde birey bakış açısıyla, bireyin okulda ve çevresinde yaşadığı sorunlarla birlikte değerlendirilmesi, ilişkilendirilmesi ve buna yönelik farklı düzeyde müdahaleler gerçekleştirilmesi söz konusudur. Okul sosyal hizmeti, okul-aile-toplum odaklı çalışmaların yapılması, öğrencilere ve ailelerine yönelik ekonomik ve sosyal desteğin artırılması, pozitif okul ikliminin oluşturulması ve toplumsal duyarlılığın arttırılması gibi müdahaleleri de bünyesinde barındırır. Ekolojik yaklaşıma dayalı etkili bir sosyal 
hizmet müdahalesi ile öğrencilerin sorunlarının ele alınması, çevrelerindeki diğer sosyal sistemlerle değerlendirilmesi ve toplumdaki ilgili kurum ve kuruluşlarla işbirliğinin sağlanmasına dikkat çekmekte fayda vardır. Okul sosyal hizmetinin ekolojik yaklaşımını temelinde bulundurması, çalışılan vakada görüldüğü üzere sosyal hizmet uzmanının sistemler arası ilişkileri analiz etme, planlı müdahale planı aşamalarına göre kuramsal yol haritasını belirleme gibi değerlendirmede ve uygulamada ciddi olumlu sonuçlar verebilmektedir. Son olarak öğrencilere etki eden biyo-psiko-sosyal faktörler üzerine odaklanılması, öğrencilerin sosyal işlevlerinin geliştirilmesi ve gereksinim duyulan hizmetlerden yararlanmaları, okula düzenli devamlarının sağlanması, akademik başarısızlık risklerinin azaltılması, erken dönemde bazı nedenlerle eğitimlerinin yarıda bırakılmasının önlenmesi gibi süreçlerin daha işlevli hale getirilmesi için okul sosyal hizmetinin uygulamaya geçirilmesi büyük önem taşımaktadır. Bundan hareketle, uygulama sürecinde okul sosyal hizmet uzmanlarının, kapsamlı ve bütünleştirici bir bakış açısıyla eğitim programlarını ve müfredatı değerlendirmesi, kişilik gelişimi, davranış problemleri için terapötik müdahale konularında öğrencilere danışmanlık vermesi ve bu konularda politika geliştirmesine zemin hazırlanmalıdır.

\section{KAYNAKÇA}

Ambrosino, R., Ambrosino, R., Heffernan, J., Shuttlesworth, G. (2008). Social work and social welfare an introduction. USA: Thomson Brooks/Cole.

Amerikan Psikiyatri Birliği. (2013). Ruhsal bozuklukların tanısal ve sayımsal elkitabı (5. Basım). DSM5 Tanı Ölçütleri Başvuru Elkitabı'ndan (Çev. Ertuğrul Köroğlu). Ankara: Hekimler Yayın Birliği.

Arıkan, Ç. (2001). Görme özürlü kadınlar: Sorunlar, beklentiler, çözüm önerileri. Ankara: Körler Federasyonu.

Barker, R. (1999). Social work dictionary. Washington, DC: NASW.

Bloom, R. J. (1982). Social support sytems and cancer: A conceptual wiew in psychosocial aspects of cancer. New York: Daven Press.

Bolley, B. (2015). Social Work Practice in Schools. Canadian Association of Social Workers; <http://www.casw-acts.ca/en/social-work-practice-schools >, (Erişim Tarihi: 13.12.2018).

Cankurtaran-Öntaş, Ö. (2001). Özürlülük ve aile politikalarl, insani gelişme ve sosyal hizmet: Prof. Dr. Nesrin Koşar’a Armağan. Yay. Haz.: Kasım Karataş ve Çiğdem Arıkan. Ankara: H.Ü. Sosyal Hizmetler Yüksekokulu. 
Caplan, G., Killilea, M. (1976). Support systems and mutual help: Multidisciplinary explorations. New York: Grune - Stratton.

Collins, D., Jordan, C. and Coleman, H. (2007). An introduction to family social work (Second edition). Belmont, CA: Thompson Brooks/Cole.

Demirbilek M. (2013). Zihinsel engelli bireylerin ve ailelerinin gereksinimleri. Turkish Journal of Family Medicine and Primary Care, 7 (3), 58-64.

Demiröz, F. (2001). Görme özürlü okullarındaki sosyal hizmet gereksinimi ve uygulamalarının değerlendirilmesi: Görme özürlüler için rehabilitasyon deneyimleri yeni rehabilitasyon politikaları ve meslek tanımları. Yay. Haz.: Kasım Karataş. Ankara: Körler Federasyonu.

Doll, E. A. (1940). The nature of mental deficiency. Psychological Review, 47 (5), 395-415.

Dupper, D. R. (2013). Okul sosyal hizmeti: Etkin uygulamalar için beceri ve müdahaleler (Çev. Prof. Dr. Yasemin Özkan, Doç. Dr. Elif Gökçearslan Çifci). İstanbul: Kapital Medya.

Duyan, V. (2010). Sosyal hizmet: Temelleri, yaklaşımları ve müdahale yöntemleri. Ankara: Sosyal Hizmet Uzmanları Derneği Genel Merkezi.

Eripek, S. (2005). Zekâ geriliği. Ankara: Kök.

Erkan, G., Koçyıldırım Ş. (1996). Zihinsel Özürlü Çocuklarla İlgili Rehabilitasyon Merkezlerindeki Sosyal Hizmet Uzmanlarının Aile ve Topluma Yönelik Görevleri (basılmamış poster bildiri). Özürlü, Kent ve Çevre Kongresi, 2-6 Aralık Ankara.

Gibelman, M. (1995). What social workers do. Washington: National Association of Social Workers.

Grossman, H. J. (1983). Classification in mental retardation. Washington, DC: American Association on Mental Deficiency.

Heward, W. L. (1996). Exceptional children. An introduction to special education (Seventh Edition). New Jersey: Prentice Hall.

Karataş, Z. (2013). İntihar sonucu ebeveyn kaybı yaşayan çocuğa yönelik sosyal hizmet müdahalesi: Bir vaka sunumu. Toplum ve Sosyal Hizmet Dergisi, 24 (2), 253-268.

Karataş, K., Gencer, E., Çalış, N. ve Ege, A. (2014). Öğrenci Sorunlarının Okul Sosyal Hizmeti Bağlamında Değerlendirilmesi. Sosyal Hizmet Sempozyumunda sunulan bildiri, Celal Bayar Üniversitesi, Manisa.

Kirst-Ashman, K. and Hull, G. H. (1999). Understanding generalist practice. Chicago: Nelson-Hall Publishers.

Koç, M. (2004). Gelişim psikolojisi açısından ergenlik dönemi ve genel özellikler. Sosyal Bilimler Enstitüsü Dergisi, 17, 231-256. 
Küçükkaraca, N. (2001). Özürlü haklarl ve sosyal hizmet mesleği: Görme özürlüler için rehabilitasyon deneyimleri, yeni rehabilitasyon politikaları ve meslek tanımları. Yay. Haz.: Kasım Karataş. Ankara: Körler Federasyonu.

Mackelprang, R. W., Salsgiver R. O. (1999). Disability: A diversity model approach in human service pratice. Canada: Brooks/Cole Publishing Company.

Miley, K. K., O’Melia, M., Dubois, B. (1998). Generalist social work practice-an empowering approach. England: Allyn and Bacon.

Nadir, U. ve Aktan, M. C. (2016). Okul sosyal hizmeti ve okul sosyal hizmet uzmanının rollerine ilişkin bir tartışma: Kurgusal bir vaka sunumu. Sağllk ve Toplum Dergisi, 25 (3), 78-88.

Neuling, S. J., Winefild, R. H. (1988). Social suport and recovery after surgery for breast cancer: Frequency and correlates of supportive behaviors by family. Social Science and Medicine, 27 (4), 385-392.

Özkan, Y. ve Kılıç, E. (2014). Çocuk ve aile odaklı sorunların çözümünde okul sosyal hizmet uzmanlarının önemi: Uzmanların çocuk ve ailelerle çalışmada sahip oldukları beceriler. Türkiye Sosyal Araştırmalar Dergisi 18 (3), 397-412.

Smith, D. D. (2007). Introduction to special education. Making a difference (Sixth Edition). Boston: Pearson.

Teater, B. (2015). Sosyal hizmet kuram ve yöntemleri. Ankara: Nika.

Tekinarslan, İ. Ç. (2013). Zihinsel Yetersizliği Olan Öğrenciler. Özel eğitime gereksinimi olan ögrenciler ve özel ĕgitim kitabı içinde (ss. 137-164). Ankara: Pegem Akademi.

Tufan, B. (1994). Göçmen işçilerde iş kazalart. Ankara: Sosyal Sigortalar Kurumu Genel Müdürlüğü.

Turan, N. (2012). Birey ve ailelerle sosyal hizmet. Ankara: Sosyal Hizmet Uzmanları Derneği Genel Merkezi.

Turnbull, T., Turnbull, A., Wehmeyer, M. L. (2007). Exceptional lives: Special education in today's school (Fifth Edition). New Jersey: Pearson Prentice Hall.

Turnbull, T., Turnbull, A., Shank, M., Smith, S., Leal, D. (2002). Exceptional lives: Special education in today's school (Third Edition). New Jersey: Merrill\&Prentice Hall.

Yıldırım, K. (2007). Sosyal hizmet. Sakarya: Sakarya Yayıncılı.

Zastrow, C. (2016). Sosyal hizmete giriş. Ankara: Nika. 